\title{
Preparation and Evaluation of some polyaniline/ cycloadductcomposites for their biocidalactivity against some biofouling-causing organisms
}

\author{
Nada Z. El-sayed, Samia A. El-Abbady, Samia M. Agamy \\ Department of chemistry, Women College for Arts, Science, and Education,Ain Shams \\ University.
}

\begin{abstract}
Cycloadducts of 3-Hydroxy-1-phenacyl pyridinium bromide (1) and 3-Hydroxy-1-(4nitrobenzyl) pyridinium chloride (2) with vinyl trimethylsilane, methyl sulfonyl chloride and vinyl triphenylphosphonium bromide were prepared. Six novel polyaniline/ cycloadduct (PANI/CY) composites were prepared by the polymerization of aniline in the presence of different weight percentages of cycloadduct were characterized using Fourier transform infrared (FTIR) spectroscopy, Mass spectrum (MS) and Nuclear magnetic resonance (NMR),Transmission electron microscopy (TEM). Their potential as antibiofouling agents was evaluated. Antimicrobial /macrobial fouling activity were conventional using inhibition zone, serial tube dilution methods and mortality tests respectively.
\end{abstract}

Key words: Cycloadduct, polyaniline, composites, biocidal activity and biofouling.

\section{Introduction}

Pyridin-3-ol and its 1-substituted pyridinium-3-olate have been used to build a variety of aza- bicycle octenone derivatives which proved to have potential as biologically active compounds.On the other handpolyaniline has a variety applications towards technology and this applications are in electrochemical devices, storage batteries, corrosion inhibitors, light emitting diodes (LED), and variety sensors. Recently studies indicate that Polyaniline (PANI) showing antibacterial properties.(Stejskal, Sapurina et al. 2010) as well asPolyaniline nanostructures and the role of aniline oligomers in their formation.

Industrial fouling involves inorganic, organic, particules and biological fouling.(Smeltzer, Nelson et al. 2008)Biofouling in industrial water systems is a difficult problem not easily controlled and even then at a significant cost.

(Venkatesan and Murthy 2008)Biofouling results from the growth of different micro and macro organisms and plants on the surfaces of submerged structures.(Anon 1952) Attaching of marine biofoulants in a remarkable numbers to submerged objects has been demonstrated by several authors as a worldwide phenomenon.(Ramadan, Kheirallah et al. 2006)Microbiofouling is indirectly related to the presence of aerobic and anaerobic microorganisms which can damage the metal by adhering to different surfaces. Relative to the bacteria, a wide diversity of taxa was used.(Dhanasekaran, Thajuddin et al. 2009)Bacteria involved in the adhesion process on artificial hard substrate are generally selected when [( AF) Antifouling] compounds for man-made devices are screened(Wilsanand, Wagh et al. 1999, Ramasamy and Murugan 2007).

*Corresponding Author: nada7med2012@gmail.com 
Cell adhesion and biofilm formation have been increasingly studied in bioassays as it appeared to be more relevant for [(AF) Antifouling] purposes than growth inhibition.(Stafslien, Bahr et al. 2006, Wicker, Sabot et al. 2007)About 150 species of macrofoulants have been listed for sea and fresh water-cooled systems, heat exchangers, power plants pipelines, tanks, and industrial equipments.(Claudi , Bott 1993, Bott 1995)

PANI is well-known for its ease of synthesis and environmental stability as a conductive electroactive polymer. Aniline or aniline hydrochloride can be polymerized to PANI by chemical or electrochemical polymerization.(Stejskal, Sapurina et al. 2010) Conductive electroactive polymers including PANI can be used as electrical conductors, batteries, chemical and biological sensors, actuators, electromagnetic shielding, antistatic coatings, corrosion protection, as well as electro-optic and electrochromic devices. The unique electrical, electrochemical, and optical properties of this polymer make it suitable for use as a healthcare material in tissue engineering, drug delivery, neural regeneration, and smart implants..Polyaniline (PANI) as a conductive polymer material, has a unique doping properties and a perfect electrochemical reversibility when it is mixed with doping acid and some nano-powder (carbon, $\mathrm{TiO}_{2}$ and so on). Compared with other polymer materials, PANI has low price, simple synthesis process and unique conductive properties and high thermal stability which make it one of the most potential conductive antifouling materials. It has been confirmed that PANI is the most promising conductive polymers and had become the focus of investigation and exploration.(Tian, Wang et al. 2010)

\section{Experimental section}

\subsection{Materials and methods}

Melting points were measured with a Gallen Kamp melting point apparatus. Silicagel-coated aluminum plates used to test the purity of the compounds. Infrared spectra $(\lambda$ $\mathrm{cm}^{-1}$ ) were recorded on a PYE-Unicamsp 300 infrared spectrometer (Ain Shams University, Egypt), using KBr disks. ${ }^{1} \mathrm{H}$ NMR spectra were recorded on Bruker $300 \mathrm{MHz}$, in DMSO-d 6 using dimethyl sulfoxide as a solvent and tetramethylsilane (TMS) as an internal standard (Chemical shift in $\delta$, ppm). Mass spectra were measured on GCQ Finnigan MAT and elemental analyses were performed at the microanalytical Center, Cairo University, Giza, Egypt. The crystal size samples have been investigated by (TEM, Model JEM-200CX, JEOLJapan), TGA measurements were carried out on a Nietzsche DSC 204 (Germany). Biological activity was determined in Petroleum Biotechnology Lab, Processes Design and Development Department, Egyptian Petroleum Research Institute (EPRI), Cairo, Egypt. All the chemicals were purchased from Sigma-Aldrich.

\subsection{General method}

Synthesis of 3-hydroxy-1-phenacyl pyridinium bromide (1) and3-hydroxy-1-(4-nitrobenzyl) pyridinium chloride (2)

3-Hydroxy-1-phenacyl pyridinium bromide (1) and3-hydroxy-1-(4-nitrobenzyl) pyridinium chloride (2) were synthesised according to the literature method (Aboelnaga and Abbady 2017), mixture of pyridin-3-ol ( $1 \mathrm{~g}, 0.01 \mathrm{~mol})$ and phenacyl bromide $(2 \mathrm{~g}, 0.01 \mathrm{~mol}$ or 4 - 
nitrobenzylchloride $(1.8 \mathrm{~g}, 0.01 \mathrm{~mol})$ in acetonitrile $(30 \mathrm{ml})$ was stirred for $4 \mathrm{~h}$ then the solvent was removed under reduced pressure. The yellow residue obtained was recrystallized from EtOH to give 3-hydroxy-1-phenacyl pyridinium bromide (1) as pale yellow crystals, (1.6 g, $80 \%)$, mp $224-226^{\circ} \mathrm{C}$.and 3-hydroxy-1-(4-nitrobenzyl) pyridinium chloride (2) as pale yellow crystals, $(2.7 \mathrm{~g}, 96 \%), \mathrm{mp} 212-214^{\circ} \mathrm{C}$.

\subsection{Cycloaddition reaction of pyridinium-3-olates (1) and (2) with different dipolarophiles. General method}

A mixture of 3-hydroxy-1-phenacyl pyridinium bromide (1) or 3-hydroxy-1-(4nitrobenzyl) pyridinium chloride(2) and dipolarophiles (vinyl trimethylsilane,methylene sulfone and vinyl triphenylphosphonium bromide) $(0.01: 0.01 \mathrm{~mol})$ in the presence of hydroquinone $(0.02 \mathrm{~g})$, triethylamine $(2 \mathrm{ml})$ was added to $20 \mathrm{ml}$ of DMF. The reaction was heated in ultrasonic bath at $40^{\circ} \mathrm{C}$, for 4 hours. At the end of the reaction, the solvent was evaporated under reduced pressure to give deep brown oil, which triturated with light petroleum b.p $40-60^{\circ} \mathrm{C}$ and then extracted with chloroform that was separated, dried over anhydrous sodium sulphate, filtered off, and evaporated under reduced pressure to give the corresponding adducts (3)-(8).

\subsubsection{Cycloaddition of 3-hydroxy-1-phenacyl pyridinium bromide (1) with vinyl trimethylsilane}

The residue obtained was recrystallized from mixed solvent methylene chloride/light petroleum b.p $40-60^{\circ} \mathrm{C}$ ether to give 8-(phenacyl)-2-oxo-8-aza-bicyclo[3.2.1]oct-3-en-6exo(trimethylsilane)(3), as brown crystals (mp 184-186 $\left.{ }^{\circ} \mathrm{C}\right),(2.32 \mathrm{~g}, 74 \%)$, it showed one spot on TLC.IR $(\mathrm{KBr}): \mathrm{v}\left(\mathrm{cm}^{-1}\right)=3463.81(\mathrm{OH}), 1683.65$ (unsaturated CO), 1705.98 (CO Ketone) and 1250.11 (Si-CH3). MS: $\mathrm{m} / \mathrm{z}=313.12\left(\mathrm{M}^{+}\right.$, 43.85\%). Anal.Calcd.For $\mathrm{C}_{18} \mathrm{H}_{23} \mathrm{NO}_{2} \mathrm{Si}$; C, 68.97; H, 7.40; N, 4.47; O, 10.21; Si, 8.96. Found; C, 68.71; H, 7.57; N, 4.63; O, 10.68; Si, 8.41. ${ }^{1} \mathrm{H}$ NMR (300 MHz, DMSO-d 6 ): $\delta(\mathrm{ppm}) 0.87\left(\mathrm{~s}, 9 \mathrm{H}, \mathrm{CH}_{3}\right) ; 1.21$ $(\mathrm{t}, 2 \mathrm{H}, \mathrm{H}-7) ; 1.50$ (q,1H, H-6); $2.51(\mathrm{~d}, 1 \mathrm{H}, \mathrm{H}-5) ; 3.07(\mathrm{t}, 1 \mathrm{H}, \mathrm{H}-1) ; 3.35\left(\mathrm{~s}, 2 \mathrm{H}, \mathrm{CH}_{2}\right) ; 6.20$ (d,1H,H-3); 6.70 (dd,1H,H-4); 7.41-7.83 (m,5H,Ar.).

\subsubsection{Cycloaddition of 3-hydroxy-1-phenacyl pyridinium bromide (1) with methylene sulfone}

The residue obtained was recrystallized from ethanol to give 8-(phenacyl)-6-thia-8azabicyclo[3.2.1] oct-3-en-2-one 6,6-dioxide (4), as light brown crystals (mp122-125 ${ }^{\circ} \mathrm{C}$ ), $(2.28 \mathrm{~g}, 78 \%)$, it showed one spot on TLC.IR $(\mathrm{KBr}): \mathrm{v}\left(\mathrm{cm}^{-1}\right)=3547.90(\mathrm{OH}), 1684.89$ (unsaturated CO), 1715.04 (CO ketone) and 1045.01 (SO).MS: $\mathrm{m} / \mathrm{z}=291.18\left(\mathrm{M}^{+}\right.$, 83.57\%)Anal.Calcd.For $\mathrm{C}_{14} \mathrm{H}_{13} \mathrm{NO}_{4} \mathrm{~S} ; \mathrm{C}, 57.72 ; \mathrm{H}, 4.50 ; \mathrm{N}, 4.81 ; \mathrm{O}, 21.79 ; \mathrm{S}, 11.01$. Found; C, 57.63; H, 4.93; N, 4.88; O, 21.36; S, 11.20. ${ }^{1} \mathrm{H}$ NMR (300 MHz, DMSO-d $\left.\mathrm{d}_{6}\right): \delta(\mathrm{ppm}) 3.41$ $(\mathrm{t}, 1 \mathrm{H}, \mathrm{H}-1) ; 3.50\left(\mathrm{~s}, 2 \mathrm{H}, \mathrm{CH}_{2}\right) ; 3.78(\mathrm{~d}, 2 \mathrm{H}, \mathrm{H}-7) ; 4.80(\mathrm{~d}, 1 \mathrm{H}, \mathrm{H}-5) ; 6.38(\mathrm{~d}, 1 \mathrm{H}, \mathrm{H}-3) ; 6.98$ (dd,1H,H-4) ; 7.11-7.94 (m,5H,Ar.).

Note: Methylene sulphone was prepared in situe by Bisetly and singh method.(Bisetty and Singh 2012) 
2.3.3. Cycloaddition of 3-hydroxy-1-phenacyl pyridinium bromide (1) with vinyl triphenylphosphonium bromide

The residue obtained was recrystallized from isopropanol to give 8-(phenacyl)-6,6,6triphenyl-7-methyl-8-aza-phosphabicyclo[3.2.1]oct-3-en-2-one(5), as brown crystals (m.p. $\left.=148-150^{\circ} \mathrm{C}\right),(3.75 \mathrm{~g}, 74 \%)$. IR $(\mathrm{KBr}): \mathrm{v}\left(\mathrm{cm}^{-1}\right)=3465.87(\mathrm{OH}), 1685.07$ (unsaturated $\mathrm{CO}$ ), 1700.01 (CO ketone) and 1458.64, 1002.97 (P-Ar).MS: $\mathrm{m} / \mathrm{z}=503.40\left(\mathrm{M}^{+}, 9.31 \%\right)$. Anal.Calcd.For $\mathrm{C}_{33} \mathrm{H}_{30} \mathrm{NO}_{2} \mathrm{P} ; \mathrm{C}, 78.87$; H, 5.82; N, 2.79; O, 6.37; P, 6.16. Found; C, 78.61; $\mathrm{H}, 5.80 ; \mathrm{N}, 2.94 ; \mathrm{O}, 6.31 ; \mathrm{P}, 6.34 .{ }^{1} \mathrm{H}$ NMR $\left(300 \mathrm{MHz}, \mathrm{DMSO}_{6}\right)$ : $\delta(\mathrm{ppm}) 1.24\left(\mathrm{~d}, 3 \mathrm{H}, \mathrm{CH}_{3}\right)$; $2.08(\mathrm{~s}, 1 \mathrm{H}, \mathrm{H}-7) ; 2.50(\mathrm{~d}, 1 \mathrm{H}, \mathrm{H}-5) ; 3.05(\mathrm{~d}, 1 \mathrm{H}, \mathrm{H}-1) ; 3.34\left(\mathrm{~s}, 2 \mathrm{H}, \mathrm{CH}_{2}\right) ; 6.20(\mathrm{~d}, 1 \mathrm{H}, \mathrm{H}-3)$; $6.70(\mathrm{dd}, 1 \mathrm{H}, \mathrm{H}-4) ; 7.56-7.81$ (m,20H,Ar).

\subsubsection{Cycloaddition of 1-(4-nitrobenzyl) pyridinium -3-olate (2) With vinyl trimethylsilane}

The residue obtained was recrystallized from ethanol to give 8-(4-nitrobenzyl)-2-oxo8-aza-bicyclo[3.2.1] bct-3-en-6-exo(trimethylsilane)(6), as brown crystals (m.p=142-144 ${ }^{\circ} \mathrm{C}$ ), $(2.54 \mathrm{~g}, 79 \%)$.It showed one spot on TLC. IR $(\mathrm{KBr}): \mathrm{v}\left(\mathrm{cm}^{-1}\right)=1689.45$ (unsaturated CO), $1526.79\left(\mathrm{NO}_{2}\right.$ group) $1260.06(\mathrm{Si}-\mathrm{CH} 3) . \mathrm{MS}: \mathrm{m} / \mathrm{z}=330.34\left(\mathrm{M}^{+}, 33.37 \%\right)$. Anal.Calcd.For $\mathrm{C}_{17} \mathrm{H}_{22} \mathrm{~N}_{2} \mathrm{O}_{3} \mathrm{Si}$; C, 61.79; H, 6.71; N, 8.48; O, 14.52; Si, 8.50. Found; C, 61.53; H, 6.44; N, 8.96; O, 14.12; Si, 8.95. ${ }^{1} \mathrm{H}$ NMR (300 MHz, DMSO-d $\left.\mathrm{d}_{6}\right): \delta$ (ppm) $0.87\left(\mathrm{~s}, 9 \mathrm{H}, \mathrm{CH}_{3}\right) ; 1.21$ $(\mathrm{t}, 2 \mathrm{H}, \mathrm{H}-7) ; 1.70$ (q,1H,H-6) ; $2.51(\mathrm{~d}, 1 \mathrm{H}, \mathrm{H}-5) ; 3.07(\mathrm{t}, 1 \mathrm{H}, \mathrm{H}-1) ; 3.35\left(\mathrm{~s}, 2 \mathrm{H}, \mathrm{CH}_{2}\right) ; 6.20$ (d,1H,H-3) ; 6.60 (dd,1H,H-4) ; 7.41-7.57 (m,4H,Ar.).

\subsubsection{Cycloaddition of 1-(4-nitrobenzyl) pyridinium -3-olate (2) with methylene sulfone}

The residue obtained was recrystallized from ethanol to give 8-(4-nitrobenzyl)-6thia-8-azabicyclo[3.2.1]oct-3-en-2-one 6,6-dioxide (7), as light brown crystals (m.p.=170$\left.172^{\circ} \mathrm{C}\right),(2.23 \mathrm{~g}, 74 \%)$.It showed one spot on TLC. IR $(\mathrm{KBr}): \mathrm{v}\left(\mathrm{cm}^{-1}\right)=1684.78$ (unsaturated $\mathrm{CO}), 1522.62\left(\mathrm{NO}_{2}\right.$ group) 1035,59 (SO). MS: m/z = $308.09\left(\mathrm{M}^{+}, 82.95 \%\right)$ Anal.Calcd.For $\mathrm{C}_{13} \mathrm{H}_{12} \mathrm{~N}_{2} \mathrm{O}_{5} \mathrm{~S} ; \mathrm{C}, 50.64 ; \mathrm{H}, 3.92 ; \mathrm{N}, 9.09 ; \mathrm{O}, 25.95 ; \mathrm{S}, 10.40$. Found; C, 50.93; H, 3.65; N, 9.45; O, 25.75; S, 10.22. ${ }^{1} \mathrm{H}$ NMR (300 MHz, DMSO-d 6 ): $\delta$ (ppm) $3.12(\mathrm{~d}, 2 \mathrm{H}, \mathrm{H}-7) ; 3.48$ $(\mathrm{t}, 1 \mathrm{H}, \mathrm{H}-1) ; 3.60\left(\mathrm{~s}, 2 \mathrm{H}, \mathrm{CH}_{2}\right) ; 4.27(\mathrm{~d}, 1 \mathrm{H}, \mathrm{H}-5) ; 5.93(\mathrm{~d}, 1 \mathrm{H}, \mathrm{H}-3)$; $6.90(\mathrm{dd}, 1 \mathrm{H}, \mathrm{H}-4)$; $7.75-$ 8.31 (m,4H,Ar.).

\subsubsection{Cycloaddition of 1-(4-nitrobenzyl) pyridinium -3-olate (2) with vinyl} triphenylphosphonium bromide

The residue obtained was recrystallized from isopropanol to give 8-(4-nitrobenzyl)6,6,6-triphenyl-7-methyl-8-aza-phosphabicyclo[3.2.1]oct-3-en-2-one (8), as brown crystals (m.p. $\left.=130-132^{\circ} \mathrm{C}\right)(3.81 \mathrm{~g}, 75 \%)$. IR $(\mathrm{KBr}): \mathrm{v}\left(\mathrm{cm}^{-1}\right)=1680.09$ (unsaturated $\left.\mathrm{CO}\right), 1519.91$ $\left(\mathrm{NO}_{2}\right.$ group) 1440.74, 1003.04 (P-Ar). MS: $\mathrm{m} / \mathrm{z}=520.12\left(\mathrm{M}^{+}, 9.91 \%\right) \mathrm{C}_{32} \mathrm{H}_{28} \mathrm{~N}_{2} \mathrm{O}_{3} \mathrm{P}$. Anal.Calcd.For $\mathrm{C}_{32} \mathrm{H}_{29} \mathrm{~N}_{2} \mathrm{O}_{3} \mathrm{P}$; C, 73.98; H, 5.43; N, 5.39; O, 9.24; P, 5.96. Found; C, 73.52; $\mathrm{H}, 5.79 ; \mathrm{N}, 5.26 ; \mathrm{O}, 9.23 ; \mathrm{P}, 6.20 .{ }^{1} \mathrm{H} \mathrm{NMR}\left(300 \mathrm{MHz}, \mathrm{DMSO}-\mathrm{d}_{6}\right): \delta(\mathrm{ppm}) 0.85\left(\mathrm{~d}, 3 \mathrm{H}, \mathrm{CH}_{3}\right)$; 2.07 (s,1H,H-7) ; $2.51(\mathrm{~d}, 1 \mathrm{H}, \mathrm{H}-5) ; 3.51(\mathrm{~d}, 1 \mathrm{H}, \mathrm{H}-1) ; 3.35\left(\mathrm{~s}, 2 \mathrm{H}, \mathrm{CH}_{2}\right) ; 6.50(\mathrm{~d}, 1 \mathrm{H}, \mathrm{H}-3)$; 6.80 (dd,1H,H-4) ; 7.53 - 7.78 (m,19H,Ar.). 


\subsection{Polymerization}

\subsubsection{Preparation of polyaniline}

To a well stirred solution of aniline $(9.3 \mathrm{ml})$ in $(20 \mathrm{ml} 1 \mathrm{M} \mathrm{HCl})$ was added dropwise a solution of Amm.peroxi disulphate $(22.8 \mathrm{~g}$ in $20 \mathrm{ml}, 1 \mathrm{M} \mathrm{HCl})$ over a period of 1 hour at $0^{\circ} \mathrm{C}$ and, freezed for 2 hours. The precipitate filtered off and washed with water then methanol and dried. (Syed and Dinesan 1992)

\subsubsection{Composite of pyridinium salts (1) and (2) with polyaniline: by blending method.}

To a $2 \mathrm{~g}$ of polyaniline was added to different weight $(0.025,0.05,0.1$, and $0.2 \mathrm{~g})$ of pyridinium salts(1) or (2) then blended well to give (9a, 9b, 9c, and 9d) and (10a, 10b, 10c and 10d) respectively.

\subsubsection{Polyaniline and cycloadduct composite: by insitue method}

To a well stirred solution of aniline $(9.3 \mathrm{ml})$ in $(20 \mathrm{ml} 1 \mathrm{M} \mathrm{HCl})$ and $0.1 \mathrm{~g}$ of different cycloadduct (3) - (8) of Amm.peroxidisulphate $(22.8 \mathrm{~g}$ in $20 \mathrm{ml}, 1 \mathrm{M} \mathrm{HCl})$ was added dropwise over a period of 1 hour at $0^{\circ} \mathrm{C}$ and, freezed for 2 hours. The precipitate filtered off then washed with water and, washed with methanol ,finally dried to give a series of new synthesised composites (11)—(16) respectively.

Composite (11) formed by using 8-(phenacyl)-2-oxo-8-aza-bicyclo[3.2.1]oct-3-en-6exo(trimethylsilane) (3) $\mathrm{IR}(\mathrm{KBr}): \mathrm{v}\left(\mathrm{cm}^{-1}\right)=3495.83(\mathrm{OH}), 1651.25$ (unsaturated $\left.\mathrm{CO}\right)$, 1242.22 (Si-CH3)..

Composite (12) formed by using 8-(phenacyl)-6-thia-8-azabicyclo[3.2.1]oct-3-en-2-one 6,6dioxide (4) $\mathrm{IR}(\mathrm{KBr}): \mathrm{v}\left(\mathrm{cm}^{-1}\right)=3440.39(\mathrm{OH}), 1564.95$ (unsaturated $\left.\mathrm{CO}\right), 1114.65$ (SO).

Composite (13) formed by using 8-(phenacyl)-6,6,6-triphenyl-7-methyl-8-azaphosphabicyclo[3.2.1]oct-3-en-2-one(5) $\quad$ IR $\quad(\mathrm{KBr}): \quad \mathrm{v} \quad\left(\mathrm{cm}^{-1}\right) \quad=3428.81(\mathrm{OH}), \quad 1648.84$ (unsaturated CO), 1479.13, 1117.55 (P-Ar.).

Composite (14) formed by using 8-(4-nitrobenzyl)-2-oxo-8-aza-bicyclo[3.2.1]oct-3-en-6exo(trimethylsilane)(6) IR ( $\mathrm{KBr}): \mathrm{v}\left(\mathrm{cm}^{-1}\right)=1680.12$ (unsaturated $\left.\mathrm{CO}\right), 1559.17\left(\mathrm{NO}_{2}\right.$ group) 1241.93 (Si-CH3).

Composite (15) formed by using 8-(4-nitrobenzyl)-6-thia-8-azabicyclo[3.2.1]oct-3-en-2-one 6,6-dioxide (7) IR (KBr): v $\left(\mathrm{cm}^{-1}\right)=1672.15$ (unsaturated $\left.\mathrm{CO}\right), 1572.66\left(\mathrm{NO}_{2}\right.$ group) 1116.85 (SO).

Composite (16) formed by using 8-(4-nitrobenzyl)-6,6,6-triphenyl-7-methyl-8-azaphosphabicyclo[3.2.1]oct-3-en-2-one (8) IR $(\mathrm{KBr}): \mathrm{v} \quad\left(\mathrm{cm}^{-1}\right)=1665.85$ (unsaturated $\mathrm{CO}), 1563.02\left(\mathrm{NO}_{2}\right.$ group)1480.10, 1119.48 (P-Ar).

\subsubsection{Preparation of Nano polyaniline}

To a well stirred solution of aniline $(9.3 \mathrm{ml})$ in $(20 \mathrm{ml} 1 \mathrm{M} \mathrm{HCl})$ and $(1 \mathrm{~g})$ surfactant (Sodium Dodecyl sulphate) a solution of Amm.peroxi disulphate $(22.8 \mathrm{~g}$ in $20 \mathrm{ml}, 1 \mathrm{M} \mathrm{HCl})$ was added dropwise over a period of 1 hour at $0^{\circ} \mathrm{C}$ and, freezed for 2 hours. The precipitate filtered off then washed with water and, washed with methanol finally, dried to give nanopolyaniline.(Jeevananda and Lee 2008) 


\subsubsection{Nano Polyaniline and cycloadduct composite: by blending method.}

To a $2 \mathrm{~g}$ of Nano polyaniline was added $0.1 \mathrm{~g}$ of different cycloadduct (3)-(8) then blended well to give a series of new synthesised nano composites $(\mathbf{1 1}(\mathbf{n})$ - $\mathbf{1 6}(\mathbf{n})$ respectively.

\section{Results and discussion}

The reaction of 3-hydroxypyridine with phenacyl bromide or 4-nitrobenzylchloride using acetonitrile as a solvent gave quaternary pyridinium salt, namely, 3-hydroxy-1-phenacyl pyridinium bromide (1) or 3-hydroxy-1- (4-nitrobenzyl)pyridinium chloride (2). Thepyridinium salts (1) or (2)mixed withtriethylamine and $2 \pi$ dipolarophiles and then the reaction mixture was heated in an ultrasonic bath at $40^{\circ} \mathrm{C}$ for $4 \mathrm{hrs}$. The in situ liberated 3hydroxy-pyridinium-3-olate was allowed to react as [4n] $\pi$ component across 2,6 positions of the pyridinium ring with vinyl trimethylsilane, methylene sulphone or vinyl triphenylphosphonium bromideto give the new cycloadducts 6-substituted 2-oxo-8-azabicyclo [3.2.1] oct-3-enes (3-5) and (6-8) respectively. The IR spectra of cycloadducts(3),(6)showed the appearance ofCO at $1683 \mathrm{~cm}^{-1}$ for conjugated carbonyl, ${ }^{1} \mathrm{H}$ NMR of (3), (6) revealed the doublet signal of H-5 (cf. Experimental part). H-5 is the key proton for differentiation between the 6-endo (kinetically controlled) and 6-exo(thermodynamically controlled) stereoisomer.H-5 displayed a doublet which is in accord with 6- exo-stereoisomer this is owing to the bulky trimethylsilyl. The 6-endo-counter stereoisomer displayed the key proton H-5 a triplet as a consequence of its coupling with H-4 and exoH-6. Furthermore, The IR spectra of cycloadducts(4),(7) showed the appearance of CO at $1684 \mathrm{~cm}^{-}$ 1 for conjugated carbonyl, ${ }^{1} \mathrm{H}$ NMR revealedthe singlet signal of methyleneprotons in the region $83.50-3.60 . p p m$,cycloadducts(4),(7) showed lack of H-6 as it is occupied by sulphone group. The IR spectra of cycloadducts(5), (8) showed the appearance of CO at $1685 \mathrm{~cm}^{-1}$ for conjugated carbonyl, ${ }^{1} \mathrm{H}$ NMR revealeda doublet signal at $0.85 \mathrm{ppm}$ for $\mathrm{CH}_{3}$ group(cf. Experimental part) which prove the migration of vinyl double bound toward the positively charged phosphorus atom left after precipitation of bromide ion by TEA, on the other hand, cycloadducts(5),(8) showed lack of H-6 as it is occupied by phosphorus atom. 


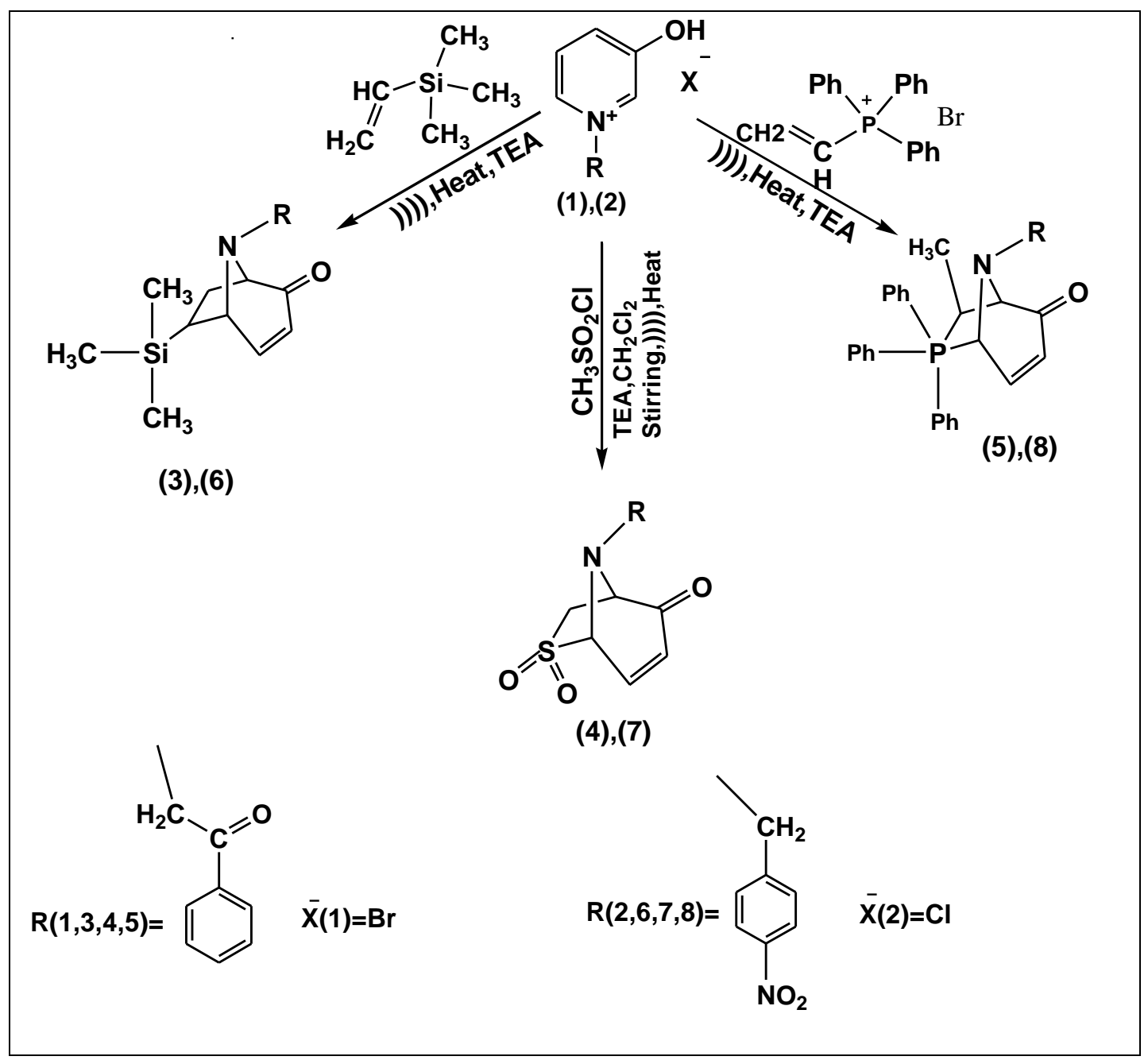

Scheme 1

In this work we have added different cycloadduct to polymer matrices to prepare novel polyaniline composites. There is an interaction between the cycloadduct and PANI in the obtained composites which have homogenous structure, the presence of the cycloadduct with the PANI increases the thermal stability of the PANI. The presence of different effective groups in cycloadduct resulted in cycloadduct homogeneity with polyaniline and its spread between chains and filling of the spaces. The difference between the two structures of cycloadduct is the activity of $\mathrm{CH}_{2}$ methylene group and the direction ofbenzenoid ring or the stereochemistry which affect its penetration into polymer matrix. TEM images of polyaniline and the prepared polyaniline/ cycloadduct composites are shown in (figs.1, 2, 3\&4) Thecycloadduct appears to fill the gaps between the polymer chains because of its large size and the spread of its molecules in the polymer matrix. Both cycloadduct of two salts have formed a nanocomposite in which different effective group did not affect image of TEM. 


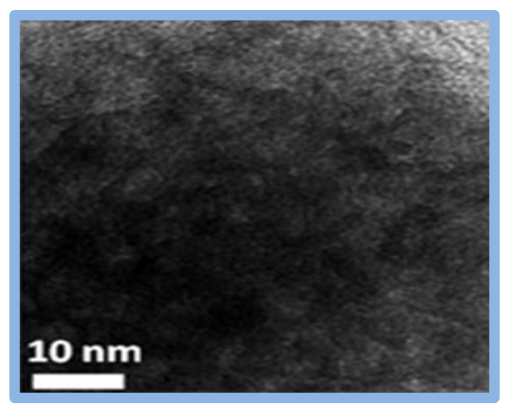

Figure 1: TEM of polyaniline

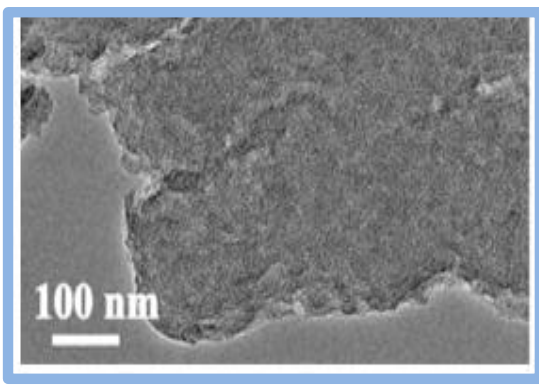

Figure 3: TEM of compounds (4)

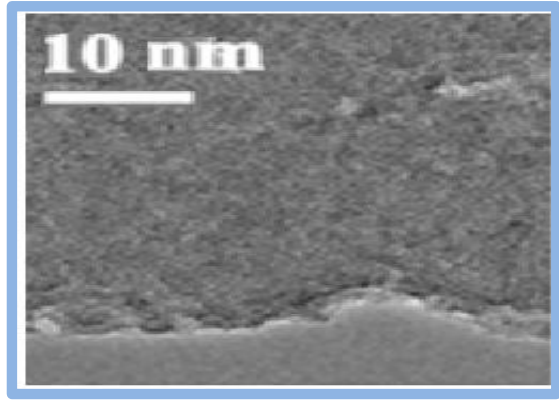

Figure 2: TEM of compounds (3)

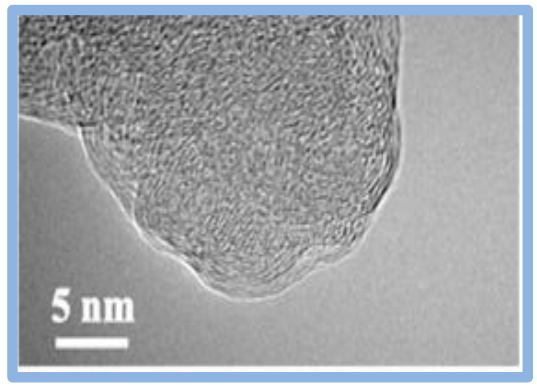

Figure 4: TEM of compounds (5)

\section{Evaluation of Antimicrobial Activity MIC\& MBC/MFC Tests}

For MIC\& MBC tests, table (1) \&figures (5-10) showed different minimum inhibition and bactericidal/ fungicidal concentrations of the twelve cycloadducts $\{13(n), 16(n), 11(n), 14(n)$, 12(n), 15(n), Comp 13, Comp 16, Comp 11, Comp 14, Comp 12 and Comp 15)compared to PANI, Comp 9 and Comp 10. Nano-cycloadducts showed higher activity followed by other cycloadducts and PANI, Comp 10 and Comp 9 respectively. In each group of cycloadducts(nano and normal sized) almost the same trend was observed: 16(n)> 14(n)> 15(n); 13(n)> 11(n)> 12(n); Comp16>Comp14>Comp15; Comp13>Comp11> Comp12; PANI $>$ Comp10 $>$ Comp9. It is already known that as the inhibition, bactericidal or fungicidal concentrations decreases this implies highest efficacy, i.e. the tested compound possesses a high toxicity so that low concentration is sufficient to cause inhibition, bactericidal or fungicidal effects. 
Table (1): Minimum inhibition concentrations (MIC) and minimum bactericidal/ fungicidal concentrations (MBC) of the twelve prepared cycloadducts

\begin{tabular}{|l|l|l|l|l|l|l|l|l|}
\hline & \multicolumn{3}{|l|}{ B. subtilis } & E. coli & \multicolumn{2}{l|}{ P. aureginosa } & \multicolumn{2}{l|}{ C. albicans } \\
\cline { 2 - 9 } & $\begin{array}{l}\mathrm{MIC} \mu \mathrm{g} / \\
\mathrm{mL}\end{array}$ & $\begin{array}{l}\mathrm{MBC} \mu \mathrm{g} / \\
\mathrm{mL}\end{array}$ & $\begin{array}{l}\mathrm{MIC} \mu \mathrm{g} / \\
\mathrm{mL}\end{array}$ & $\begin{array}{l}\mathrm{MBC} \mu \mathrm{g} / \\
\mathrm{mL}\end{array}$ & $\begin{array}{l}\mathrm{MIC} \mu \mathrm{g} / \\
\mathrm{mL}\end{array}$ & $\begin{array}{l}\mathrm{MBC} \mu \mathrm{g} / \\
\mathrm{mL}\end{array}$ & $\begin{array}{l}\mathrm{MIC} \mu \mathrm{g} / \\
\mathrm{mL}\end{array}$ & $\begin{array}{l}\mathrm{MFC} \mu \mathrm{g} / \\
\mathrm{mL}\end{array}$ \\
\hline $\mathbf{1 6 ( n )}$ & 0.0937 & 0.1875 & 2.5000 & 2.5000 & 2.5000 & 2.5000 & 0.0937 & 0.0937 \\
\hline $\mathbf{1 3 ( n )}$ & 0.1875 & 0.1875 & 2.5000 & 5.0000 & 5.0000 & 5.0000 & 0.0937 & 0.1875 \\
\hline $\mathbf{1 4 ( n )}$ & 0.1875 & 0.3750 & 2.5000 & 5.0000 & 5.0000 & 5.0000 & 0.1875 & 0.3750 \\
\hline $\mathbf{1 1}(\mathbf{n})$ & 0.3750 & 0.7500 & 5.0000 & 5.0000 & 5.0000 & 5.0000 & 0.3750 & 0.7500 \\
\hline $\mathbf{1 5}(\mathbf{n})$ & 0.7500 & 1.2500 & 5.0000 & 5.0000 & 5.0000 & 5.0000 & 0.7500 & 1.2500 \\
\hline $\mathbf{1 2 ( n )}$ & 1.2500 & 2.5000 & 5.0000 & 5.0000 & 5.0000 & 5.0000 & 1.2500 & 2.5000 \\
\hline $\begin{array}{l}\text { Comp1 } \\
\text { 6 }\end{array}$ & 5.0000 & 5.0000 & 2.5000 & 2.5000 & 2.5000 & 2.5000 & 5.0000 & 5.0000 \\
\hline $\begin{array}{l}\text { Comp1 } \\
\mathbf{3}\end{array}$ & 5.0000 & 5.0000 & 10.0000 & 5.0000 & 10.0000 & 10.0000 & 5.0000 & 5.0000 \\
\hline $\begin{array}{l}\text { Comp1 } \\
\mathbf{4}\end{array}$ & 10.0000 & 5.0000 & 5.0000 & 5.0000 & 5.0000 & 5.0000 & 10.0000 & 5.0000 \\
\hline $\begin{array}{l}\text { Comp1 } \\
\mathbf{1}\end{array}$ & 10.0000 & 10.0000 & 10.0000 & 10.0000 & 10.0000 & 10.0000 & 10.0000 & 10.0000 \\
\hline $\begin{array}{l}\text { Comp1 } \\
\mathbf{5}\end{array}$ & 10.0000 & 10.0000 & 20.0000 & 10.0000 & 20.0000 & 20.0000 & 10.0000 & 10.0000 \\
\hline $\begin{array}{l}\text { Comp1 } \\
\mathbf{2}\end{array}$ & 20.0000 & 20.0000 & 10.0000 & 10.0000 & 10.0000 & 10.0000 & 20.0000 & 10.0000 \\
\hline PANI & 10.0000 & 10.0000 & 10.0000 & 5.0000 & 10.0000 & 5.0000 & 10.0000 & 10.0000 \\
\hline Comp9 & 10.0000 & 10.0000 & 10.0000 & 10.0000 & 10.0000 & 10.0000 & 10.0000 & 10.0000 \\
\hline $\begin{array}{l}\text { Comp1 } \\
\text { 0 }\end{array}$ & 10.0000 & 10.0000 & 20.0000 & 10.0000 & 20.0000 & 20.0000 & 10.0000 & 10.0000 \\
\hline
\end{tabular}

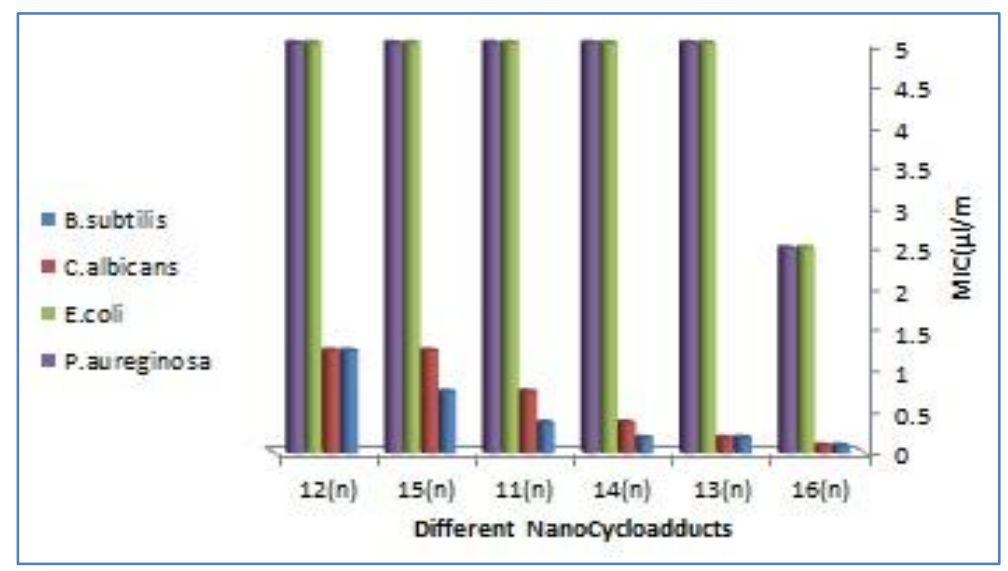

Figure (5): Minimum inhibition concentrations (MIC $\mu \mathrm{l} / \mathrm{ml}$ ) of the Nano cycloadducts 16(n), 13(n), 14(n), 11(n), 15(n) and 12(n) against Bacillus subtilis, Candida albicans, Escherichia coli and Pseudomonas aureginosa by serial dilution method. 


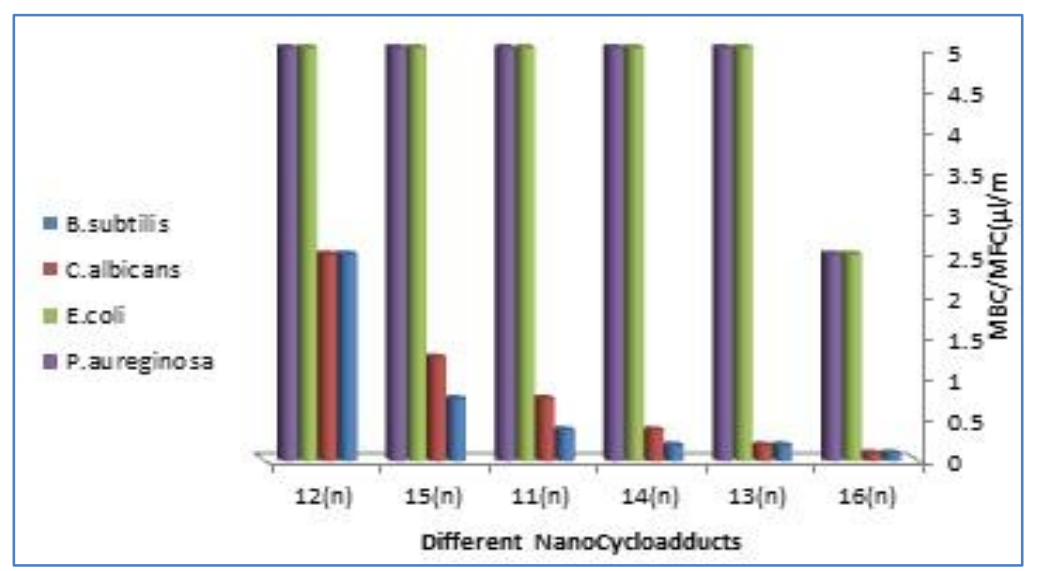

Figure (6): Minimum bactericidal/fungicidal concentrations (MBC/MFC $\mu \mathrm{l} / \mathrm{ml}$ ) of the Nano cycloadducts 16(n), 13(n), 14(n), 11(n), 15(n) and 12(n)against Bacillus subtilis, Candida albicans, Escherichia coli and Pseudomonas aureginosa determined by sub culturing broth dilutions that cease growth of bacterial/ mold organisms (i.e., those at or above the MIC).

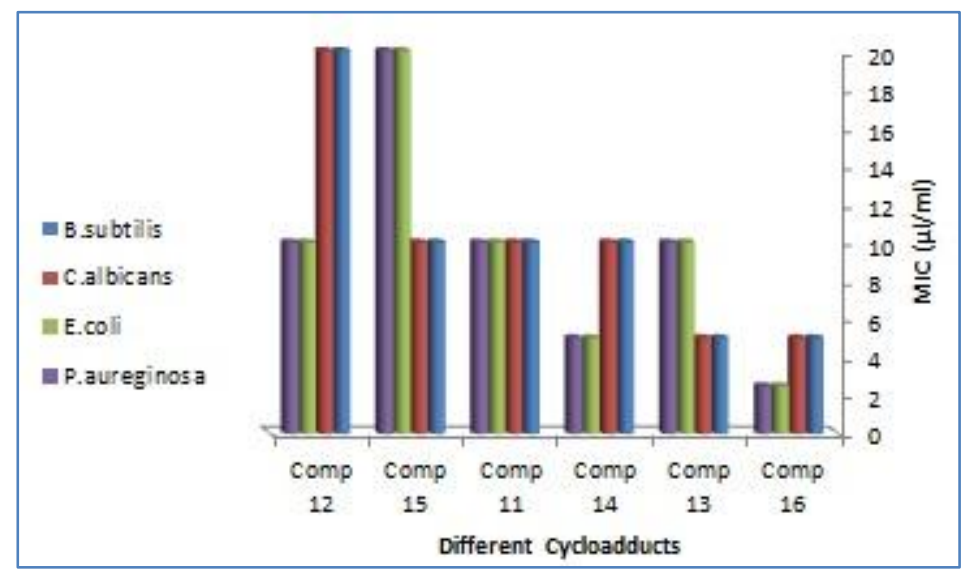

Figure (7): Minimum inhibition concentrations (MIC $\mu \mathrm{l} / \mathrm{ml}$ ) of the cycloadducts Comp16, Comp13, Comp14, Comp11, Comp15 and Comp12 against Bacillus subtilis, Candida albicans, Escherichia coli and Pseudomonas aureginosa by serial dilution method.

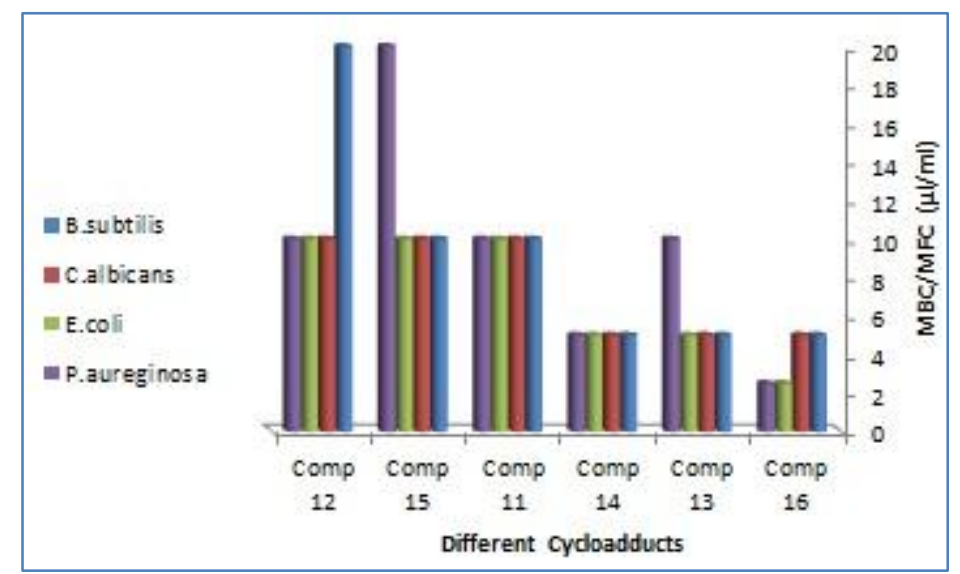

Figure (8): Minimum bactericidal/fungicidal concentrations (MBC/MFC $\mu \mathrm{l} / \mathrm{ml}$ ) of the cycloadducts Comp16, Comp13, Comp14, Comp11, Comp15 and Comp12 against Bacillus subtilis, Candida albicans, Escherichia coli and Pseudomonas aureginosa 
determined by sub culturing broth dilutions that cease growth of bacterial/ mold organisms (i.e., those at or above the MIC).

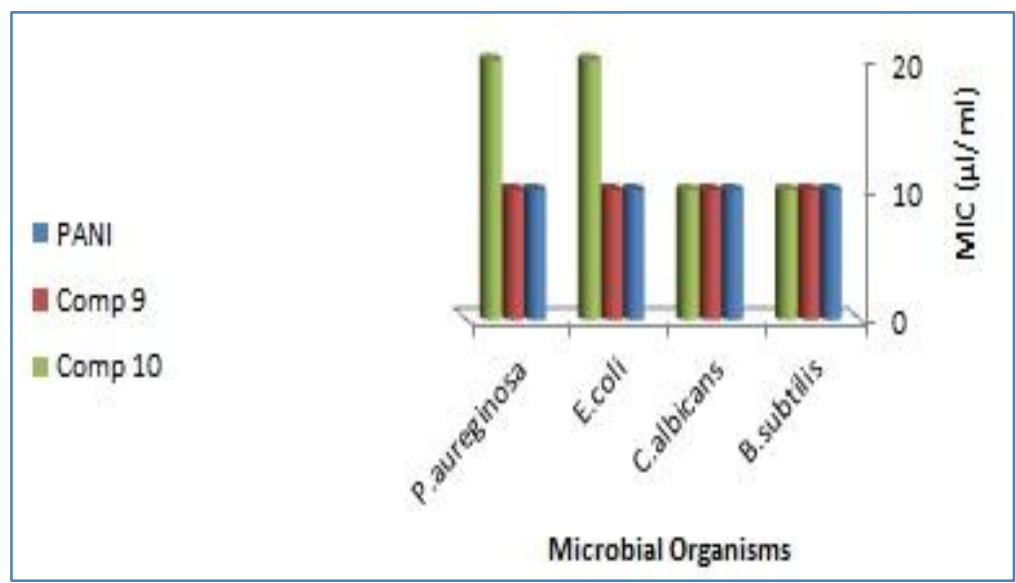

Figure (9): Minimum inhibition concentrations (MIC $\mu \mathrm{l} / \mathrm{ml}$ ) of PANI, Comp 9 and Comp 10 against Bacillus subtilis, Candida albicans, Escherichia coli and Pseudomonas aureginosa by serial dilution method.

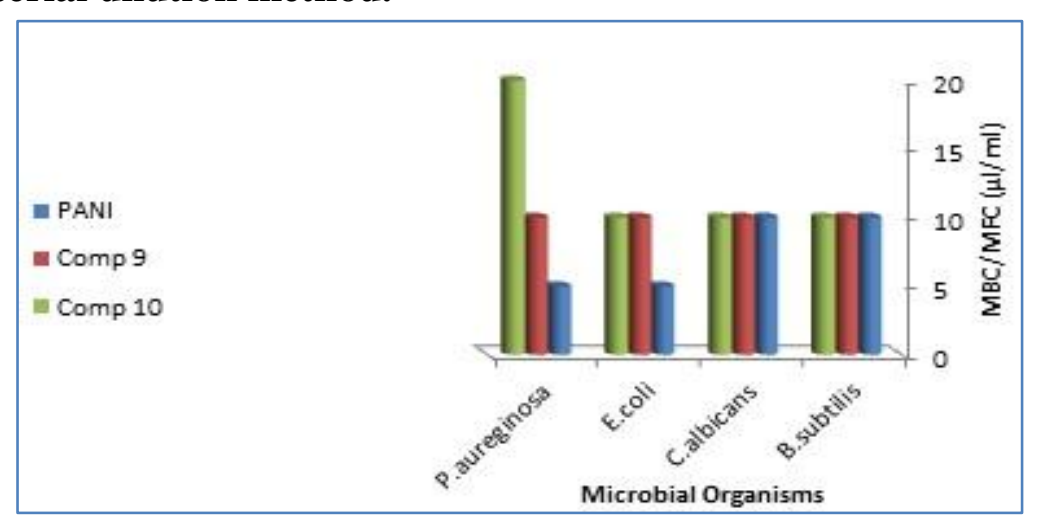

Figure (10): Minimum bactericidal/fungicidal concentrations $(\mathrm{MBC} / \mathrm{MFC} \mu \mathrm{l} / \mathrm{ml})$ of PANI, Comp 9 and Comp 10 against Bacillus subtilis, Candida albicans, Escherichia coli and Pseudomonas aureginosa determined by sub culturing broth dilutions that cease growth of bacterial/mold organisms (i.e., those at or above the MIC).

As to the suggested mode of action, according to recorded results, cycloadducts of 4nitro benzyl compounds (Comp16, Comp 14 and Comp 15) possessed the highest potent efficacy against the tested organisms (Bacillus subtilis, Pseudomonas aureginosa and Escherichia coli and Candida albicans) (the potency differs according to the type of the organism as previously mentioned above) (figs.6\&7)\& (Table 1). As nitro compounds constitute a large group of chemicals that are characterized by the presence of one or more nitro groups(Race, Lovering et al. 2005), their toxic effects have been expressed in multiple applications including antimicrobial agents.(Spain 1995, Traversi, Degan et al. 2009)Thus, enzymatic reduction is essential for the nitro compounds to exercise their cytotoxic effects, and most nitro aromatics should undergo enzymatic reduction in organisms .(Bryant and McElroy 1991, Lee, Matheson et al. 1991, Race, Lovering et al. 2005)The nitro reductases proteins form a group of enzymes that have a central role in the reduction of nitro groups on nitro compounds.(Bryant and McElroy 1991, Lee, Matheson et al. 1991)Nitroreductases comprise a family of proteins with conserved sequences that were originally discovered in 
eubacteria and have been grouped together based on their sequence similarity .(Bryant, McCalla et al. 1981)These enzymes are capable of catalyzing the reduction of nitro substituted compounds using flavin mononucleotide (FMN) or flavin adenine dinucleotide (FAD) as prosthetic groups and nicotinamide adenine dinucleotide (NADH) or nicotinamide adenine dinucleotide phosphate (NADPH) as reducing agents .(Bryant, McCalla et al. 1981, Bryant and McElroy 1991, Lee, Matheson et al. 1991)

On the other hand, carbonyl reductases enzymes are considered to be responsible for reduction of carbonyl groups of the other tested cycloadducts (Comp 13, Comp 11 and Comp 12) in cell metabolism of the tested organisms. Furthermore, coupling of two carbonyl groups together with cross linked hydrogen bond could be regarded as another obstacle causing lower efficacies of these cycloadducts(Bryant, McCalla et al. 1981, Navarre and Schneewind 1999, Ghosh, Sawicki et al. 2001, Doorn, Maser et al. 2004, Gilbert, Failli et al. 2006, Bains, Karkling et al. 2009, El-Hawari, Favia et al. 2009, Tchatalbachev, Ghai et al. 2010)

Particularly speaking, the highest efficacies belonged to Phosphoniumcycloadducts (Comp $16 \&$ Comp 13) which may be referred to the presence of three phenyl groups, while silylcycloadducts (Comp 14\& Comp 11) had three attached methyl groups, and in case of Thiacycloadducts (Comp15\& Comp 12) there are no alkyl groups(as Active, Kawabata and Nishiguchi 1988, Badawi and Hafiz 2007). Considering the foregoing mode of action, the ROS-induced oxidative stress is an important antimicrobial mechanism of the tested nanocycloadducts.ROS (reactive oxygen species) is the reactive intermediates that have strong positive redox potential that differs with different types of nanomaterials and consequently producing different types of ROS by reducing oxygen molecules. There after exhibit different levels of dynamics and activity.(Gurunathan, Han et al. 2012)As a result of excessive production of ROS causes unbalanced state producedoxidative stress which damages the individual components of bacterial cells expressing the inhibition, bactericidal/ fungicidal efficacy(Li, Zhang et al. 2012, Peng, Ni et al. 2013)

\section{Evaluation of Antifouling Activity}

Polyaniline compounds have been proved to display biofouling (corrosion-prevention behavior).(Wang, Li et al. 1999). Toxicity of different cycloadducts against the macrofoulantsModiolus articulates $\left(\mathrm{LC}_{50}\right)$ : Results of acute toxicity of the tested potent nanocycloadducts (i.e. $96 \mathrm{~h} \mathrm{LC}_{50}$ ) (Figures 11\& 12) were as follows: 16(n): $1.3 \mathrm{ppm} ; 14(\mathrm{n})$ : 1.4 ppm; 15(n): 1.5 ppm; 13(n): 1.6 ppm; 11(n): 1.65 ppm and 12(n): 2.0 ppm. Cytotoxicity of nitro compounds together with lower carbonyl cross linking in 4- nitro benzyl pyridiniumcycloadducts compared to higher carbonyl groups cross linking may explain the efficacy direction of both cycloadducts. (as Active, Moreno and Docampo 1985, Kawabata and Nishiguchi 1988, Livingstone 1991, Badawi and Hafiz 2007, Ju and Parales 2010) 


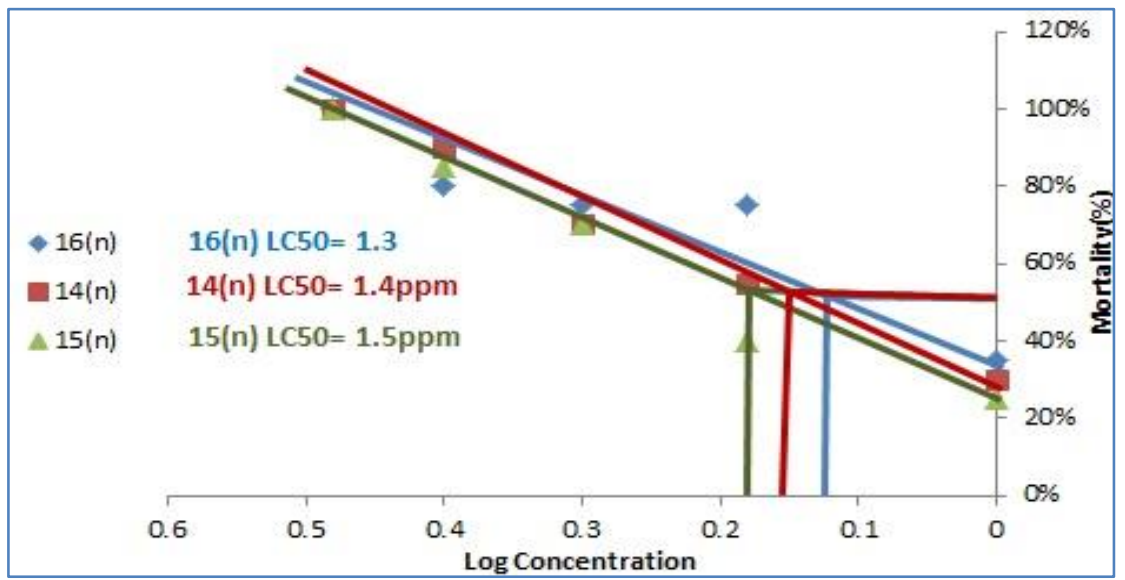

Figure (11): Toxicity of the nanocycloadduct 16(n); 14(n) and 15(n) (96h LC50) against the adult mussels Modiolus articulates.

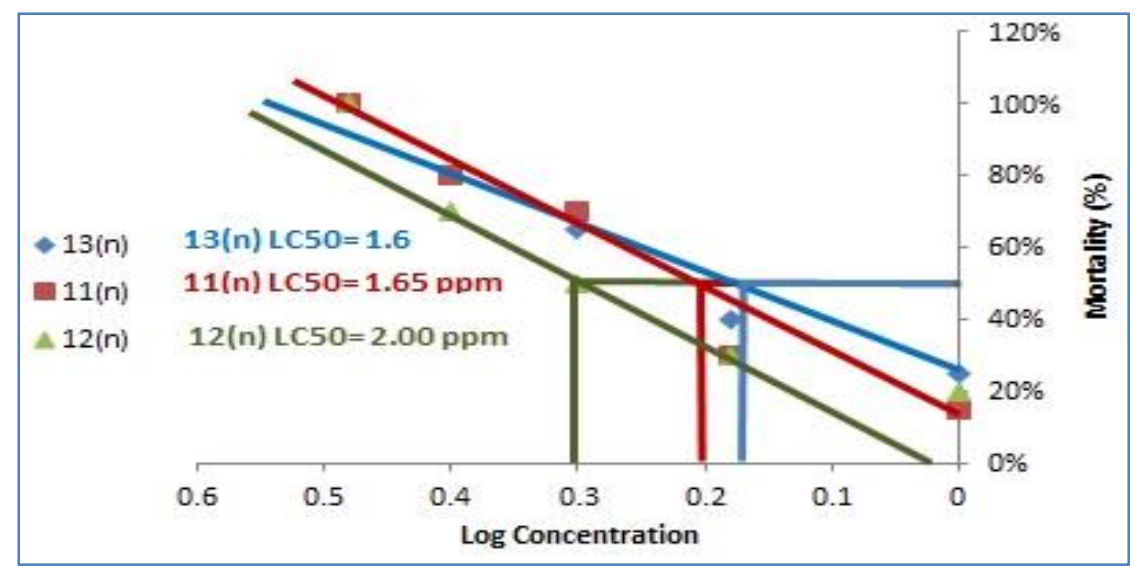

Figure (12): Toxicity of the nanocycloadduct 13(n); 11(n) and 12(n) $\left(96 \mathrm{~h} \mathrm{LC}_{50}\right)$ against the adult mussels Modiolus articulates.

\section{Toxicity of potent nanocycloadducts against non- target sea organisms}

The nanocycloadducts $13(\mathrm{n}) ; 11(\mathrm{n})$ and $12(\mathrm{n})$ caused $17 \%$ mortality against both of the amphipods Leucothoeacanthopus and the isopods Cirolana bovinaand 10\% mortality against Mugilseheli fingerlings at $2.0 \mathrm{ppm} ; 2.5 \mathrm{ppm}$ and $3.0 \mathrm{ppm}$ respectively after $96 \mathrm{~h}$ of exposure. On the other hand, $20 \%$ mortality of Leucothoeacanthopus, Cirolana bovina and $12.5 \%$ mortality ofMugilseheli fingerlings were obtained at $1.0 \mathrm{ppm} ; 1.5 \mathrm{ppm}$ and $2.0 \mathrm{ppm}$ of $16(n) ; 14(n)$ and $15(n)$ respectively after $96 \mathrm{~h}$ of exposure. Thus, the nanocycloadducts $\{13(n) ; 11(n)$ and $12(n)\}$ showed a considerably less toxicity than in case of 16(n); 14(n) and 15(n) against non-target sea organisms.

\section{Conclusion}

Among the prepared cycloadducts, nano- cycloadducts of 4-nitrobenzyl pyridinium $\{16(\mathrm{n})$; 14(n) and 15(n)were observed to be the most potent antimicrobial/antifouling agents considering their toxicity against non- target sea organisms. The nanocycloadductphosphonium of 4-nitrobenzyl pyridinium $\{16(n)\}$ appeared to be on the top of the list followed by $14(\mathrm{n})$ and $15(\mathrm{n})$ respectively. 


\section{References}

Aboelnaga, A. and S. Abbady (2017). "Ball Milling Assisted 1, 3-Dipolar Cycloaddition Reaction of 1-(4-Nitrobenzyl)-pyridinium-3-olate." Indian Journal of Heterocyclic Chemistry 27(4): 423-430.

Anon, M. (1952). "Fouling and its Prevention." Woods Hole Oceanographic Institute, US Naval Institute, Annapolis, US.

Rafat M. Mohareb, Abdelfatah M. Badawi, Mahmoud R. Noor El-Din, Nesreen A. Fatthalah \& Marian R. Mahrous."

Badawi, A. and A. Hafiz (2007). "Synthesis and immunomodulatory activity of some novel amino acid germinates." Journal of the Iranian Chemical Society 4(1): 107-113.

Bains, O. S., M. J. Karkling, T. A. Grigliatti, R. E. Reid and K. W. Riggs (2009). "Two nonsynonymous single nucleotide polymorphisms of human carbonyl reductase 1 demonstrate reduced in vitro metabolism of daunorubicin and doxorubicin." Drug Metabolism and Disposition.

Bisetty, K. and P. Singh (2012). "Cycloaddition reactions of Azatrienes with Sulfene."

Bott, T. (1993). Aspects of biofilm formation and destruction, De Gruyter.

Bott, T. R. (1995). Fouling of heat exchangers, Elsevier.

Bryant, C. and W. McElroy (1991). Chemistry and biochemistry of flavoenzymes, CRC Press Boca Raton, FL. 2: pp. 295-297.

Bryant, D., D. McCalla, M. Leeksma and P. Laneuville (1981). "Type I nitroreductases of Escherichia coli." Canadian Journal of Microbiology 27(1): 81-86.

Claudi, R. i Mackie, GL, 1994. Practical manual for zebra mussel monitoring and control, Lewis publishers, Boca Raton, Florida.

Dhanasekaran, D., N. Thajuddin, M. Rashmi, T. Deepika and M. Gunasekaran (2009). "Screening of biofouling activity in marine bacterial isolate from ship hull." International Journal of Environmental Science \& Technology 6(2): 197-202.

Doorn, J. A., E. Maser, A. Blum, D. J. Claffey and D. R. Petersen (2004). "Human carbonyl reductase catalyzes reduction of 4-oxonon-2-enal." Biochemistry 43(41): 13106-13114.

El-Hawari, Y., A. D. Favia, E. S. Pilka, M. Kisiela, U. Oppermann, H.-J. Martin and E. Maser (2009). "Analysis of the substrate-binding site of human carbonyl reductases CBR1 and CBR3 by site-directed mutagenesis." Chemico-biological interactions 178(1-3): 234241. 
Ghosh, D., M. Sawicki, V. Pletnev, M. Erman, S. Ohno, S. Nakajin and W. L. Duax (2001). "Porcine carbonyl reductase: structural basis for a functional monomer in short-chain dehydrogenases/reductases." Journal of Biological Chemistry.

Gilbert, A. M., A. Failli, J. Shumsky, Y. Yang, A. Severin, G. Singh, W. Hu, D. Keeney, P. J. Petersen and A. H. Katz (2006). "Pyrazolidine-3, 5-diones and 5-hydroxy-1 H-pyrazol-3 $(2 \mathrm{H})$-ones, inhibitors of UDP-N-acetylenolpyruvyl glucosamine reductase." Journal of medicinal chemistry 49(20): 6027-6036.

Gurunathan, S., J. W. Han, A. A. Dayem, V. Eppakayala and J.-H. Kim (2012). "Oxidative stress-mediated antibacterial activity of graphene oxide and reduced graphene oxide in Pseudomonas aeruginosa." International journal of nanomedicine 7: 5901.

Jeevananda, T. and J. H. Lee (2008). "Preparation of polyaniline nanostructures using sodium dodecylsulphate." Materials Letters 62(24): 3995-3998.

Ju, K.-S. and R. E. Parales (2010). "Nitroaromatic compounds, from synthesis to biodegradation." Microbiology and molecular biology reviews 74(2): 250-272.

Kawabata, N. and M. Nishiguchi (1988). "Antibacterial activity of soluble pyridinium-type polymers." Applied and Environmental Microbiology 54(10): 2532-2535.

Lee, J., I. Matheson, F. Müller, D. O'Kane, J. Vervoort and A. Visser (1991). Chemistry and Biochemistry of Flavoenzymes (Mü ller, F., ed) Vol. 2, CRC Press, Boca Raton, FL.

Li, Y., W. Zhang, J. Niu and Y. Chen (2012). "Mechanism of photogenerated reactive oxygen species and correlation with the antibacterial properties of engineered metal-oxide nanoparticles." ACS nano 6(6): 5164-5173.

Livingstone, D. R. (1991). Organic xenobiotic metabolism in marine invertebrates. Advances in comparative and environmental physiology, Springer: 45-185.

Moreno, S. and R. Docampo (1985). "Mechanism of toxicity of nitro compounds used in the chemotherapy of trichomoniasis." Environmental Health Perspectives 64: 199.

Navarre, W. W. and O. Schneewind (1999). "Surface proteins of gram-positive bacteria and mechanisms of their targeting to the cell wall envelope." Microbiology and molecular biology reviews 63(1): 174-229.

Peng, Z., J. Ni, K. Zheng, Y. Shen, X. Wang, G. He, S. Jin and T. Tang (2013). "Dual effects and mechanism of $\mathrm{TiO} 2$ nanotube arrays in reducing bacterial colonization and enhancing C3H10T1/2 cell adhesion." International journal of nanomedicine 8: 3093.

Race, P. R., A. L. Lovering, R. M. Green, A. Ossor, S. A. White, P. F. Searle, C. J. Wrighton and E. I. Hyde (2005). "Structural and mechanistic studies of escherichia coli nitroreductase with the antibiotic nitrofurazone reversed binding orientations in different redox states of the enzyme." Journal of Biological Chemistry 280(14): 13256-13264. 
Ramadan, S. E., A. Kheirallah and K. M. Abdel-Salam (2006). "Marine fouling community in the Eastern harbour of Alexandria, Egypt compared with four decades of previous studies." Mediterranean Marine Science 7(2): 19-30.

Ramasamy, M. S. and A. Murugan (2007). "Fouling deterrent chemical defence in three muricid gastropod egg masses from the Southeast coast of India." Biofouling 23(4): 259265 .

Smeltzer, M. S., C. L. Nelson and R. P. Evans (2008). Biofilms and aseptic loosening. The Role of Biofilms in Device-Related Infections, Springer: 57-74.

Spain, J. C. (1995). "Biodegradation of nitroaromatic compounds." Annual Reviews in Microbiology 49(1): 523-555.

Stafslien, S. J., J. A. Bahr, J. M. Feser, J. C. Weisz, B. J. Chisholm, T. E. Ready and P. Boudjouk (2006). "Combinatorial materials research applied to the development of new surface coatings I: a multiwell plate screening method for the high-throughput assessment of bacterial biofilm retention on surfaces." Journal of combinatorial chemistry 8(2): 156-162.

Stejskal, J., I. Sapurina and M. Trchová (2010). "Polyaniline nanostructures and the role of aniline oligomers in their formation." Progress in Polymer Science 35(12): 1420-1481.

Syed, A. A. and M. K. Dinesan (1992). "Anion-exchange studies on electrically conducting polymers: polyanilines." Reactive polymers 17(2): 145-157.

Tchatalbachev, S., R. Ghai, H. Hossain and T. Chakraborty (2010). "Gram-positive pathogenic bacteria induce a common early response in human monocytes." BMC microbiology 10(1): 275.

Tian, H., Y. Wang, Z. Xue, K. Cheng, Y. Qu, F. Chai and J. Hao (2010). "Trend and characteristics of atmospheric emissions of $\mathrm{Hg}$, As, and $\mathrm{Se}$ from coal combustion in China, 1980-2007." Atmospheric Chemistry and Physics 10(23): 11905-11919.

Traversi, D., R. Degan, R. De Marco, G. Gilli, C. Pignata, S. Villani and R. Bono (2009). "Mutagenic properties of PM2. 5 urban pollution in the northern Italy: the nitrocompounds contribution." Environment International 35(6): 905-910.

Venkatesan, R. and P. S. Murthy (2008). "Macrofouling control in power plants."

Wang, X.-H., J. Li, J.-Y. Zhang, Z.-C. Sun, L. Yu, X.-B. Jing, Z.-X. Sun and Z.-J. Ye (1999). "Polyaniline as marine antifouling and corrosion-prevention agent." Synthetic Metals 102(1-3): 1377-1380.

Wicker, T., F. Sabot, A. Hua-Van, J. L. Bennetzen, P. Capy, B. Chalhoub, A. Flavell, P. Leroy, M. Morgante and O. Panaud (2007). "A unified classification system for eukaryotic transposable elements." Nature Reviews Genetics 8(12): 973. 
Wilsanand, V., A. Wagh and M. Bapuji (1999). "Antifouling activities of marine sedentary invertebrates. on some macrofoulers."

\title{
الملخص باللغة العربية
}

تحضير بعض المركبات الحلقيه مع البولي انيلين و تقيم تاثير ها البيولجى ضد بعضالكائنات المسببة للتثلوث النفطي

\author{
ندا زكريا السيد و ساميه عبداللطيف العبادى ، ساميه ميشيل عجمى \\ قسم الكيمياء ــ كلية البنات للاداب و العلوم و التربيه ـ جامعة عين شمس.
}

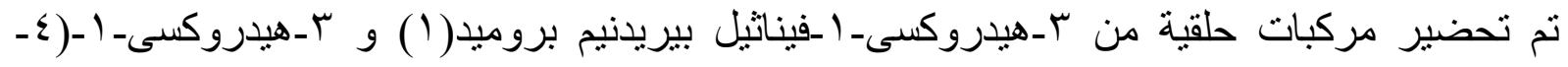
نيترو بنزيل ) بيريدنيم كلوريد(Y) مع فينايل ثلاثى ميثيل سيلان، ميثيل سلفونيل كلوريد و فينايل ثلاثي فينيل فوسفونيم بروميد.تم تحضير مركبات حلقية مع البولى انيلينبو اسطة بلمرةالانيلين فى وجود نسب مختلفه من وزن المركبات الحلقيه التى تم اثباتها باستخدام التحليل الطيفى للاشعة التحت الحمر اء، طيف الكتله ،الرنين المغناطيسى النووى والميكروسكوب الالكترونى الانتقالى.تم تقيم احتماليتهم كموانع للرواسب البتروليه. تقييم مضادات الميكروبات و النشاط البيولوجي بواسطة منطقة التثبط ، أساليب التخفيف من الأنبوب المتسلسل و اختبار ات الوفيات على التوالي. 